Dr Dion Kooijman studled archtecture in Delft and graduated in 1985 Subsequently he worked for. among others. Rotterdam Urban Council and the Erasmus Lniversity of Rotterdam (Faculty of Management). Since 1990 he has worked for the Technical University of Delft. first for the OTB Research Institute and since November 1999. in the Department of Real Estate and Land Management at the Faculty of Archtecture.

Keywords:

lessure, urban entertainment, the Netherlands
Dion C. Kooijman

Faculty of Architecture

Delft University of Technology

PO Box 5043

$2600 \mathrm{GA}$ Delf

The Netherlands

Tel: +31 (o) 152785890

Fax: +31(0)15 2783171

E-maıl: D.C Koolıman@bk.tudelft nl

\section{A third revolution in retail? The Dutch approach to leisure and urban entertainment}

\author{
Dion Kooijman
}

Recesved (in revised form) 16 April 2002

\begin{abstract}
The aim of this paper is to develop a clear framework of the relationships between real estate, leisure, urban entertainment and retail, drawing on historical and recent experience in the Netherlands. The relationships between leisure and urban entertainment are of great interest to the retail and real estate sectors - both inside and outside the Netherlands - and have the potential to generate productivity for the former and profitability for the latter. Yet opinion and thinking on the subject are highly fragmented and there are both optimism and uncertainty about its future prospects. This paper provides a description of those contending views and puts forward the proposition that leisure and urban entertainment could signal a third revolution in the retail sector.
\end{abstract}

\section{INTRODUCTION}

Leisure and urban entertainment are new concepts. Leisure stands for recreation and all kinds of cultural activities. A short definition of urban entertainment is 'leisure within an atmosphere of city life'. The concepts of leisure and urban entertainment are full of promise. In short, they can make the retail sector more productive and the real estate sector more profitable. At the same time, they are vague concepts. The vagueness comes not just from the 'newness' but also from the relationships that leisure and urban entertainment have with existing activities in society, such as real estate and retailing. And not only functional characteristics are involved. Imagination, expectation etc are part of this complexity as well. This is what the so-called experience economy is all about.

The objective of this paper is to paint a more coherent and logical picture of the relationships between leisure, urban entertainment, retail and real estate. It hopes to make clear that these relationships are not solely the integration of two different worlds, the world of leisure and that of retail, but also the transformation of retail itself. While others have already put forward theories about two revolutions in retail, ${ }^{1}$ this paper will put forward the hypothesis of a third retail revolution - a revolution that is active on many fronts with new offerings, new suppliers and a new type of consumer behaviour. Although the phenomenon of merchandising is extremely important for retail and retail real 


\section{Structure of the paper}

Four Dutch cases

Definitions estate, this paper will cover mainly the issue from the retail perspective.

The structure of the paper is borrowed from research methodology in which topical questions such as "what', "who", 'where', 'when', 'how' and 'why' are used to provide direction in describing problems. The first four have a descriptive role; the last two are more explanatory.

'What' first provides a short definition of leisure and urban entertainment, then discusses changing consumer activity and finally describes a number of features of the transformation of retailing in urban entertainment. 'Who' encompasses the group of initiators, from retailers to 'industry outsiders' such as oil and telephone companies. 'Where' is concerned with relevant aspects and developments in various countries, for which the Netherlands provides an important reference point. 'When' describes important turning points in history. 'How' is restricted to the relationship between consumption and the retail area and describes the means of interactivity. 'Why' further explains the proposition of a third revolution in retail.

Four Dutch projects have been used to try to illustrate the proposition and give it more depth. No more and no less; naturally the number is too small to draw any valid statistical conclusions. The projects are part of an intermezzo between the first five topical questions, from the 'what' to the 'how', and the last and most difficult one about the 'why'. Differences between countries as far as these concern imitatation and implementation retail and real estate formulas are becoming smaller and smaller. The speed of exchange is at high levels. This is not a paper about planning policies, but the phenomenon seems to be true for this field as well: planning policies in the different countries in the Western world are more and more the same. ${ }^{2}$

\section{WHAT: LEISURE AND URBAN ENTERTAINMENT}

Leisure is the English term for activities that are concerned with recreation, culture, sport and relaxation. Urban entertainment is leisure in an urban environment. Leisure and urban entertainment take the form of shops, catering and enjoyment. In the words of the Urban Land Institute (ULI), an urban entertainment centre is 'a new form of shopping centre that must contain three basic components: at least one pure entertainment attraction, usually a new generation cinema complex; theme restaurant; and entertainment-oriented shops in a coordinated, intense sociable environment that draws large and diverse audiences throughout the day to activate the place'. ${ }^{3}$ These definitions of urban entertainment warrant a number of observations.

The definitions, like the expectations that they raise, seem in practice to diverge. Definitions and expectations are driving the inescapable transformation that the retail sector is undergoing. Figure 1 is an illustration of a reconstruction of views and 
Passivity

\section{Consumer behaviour}

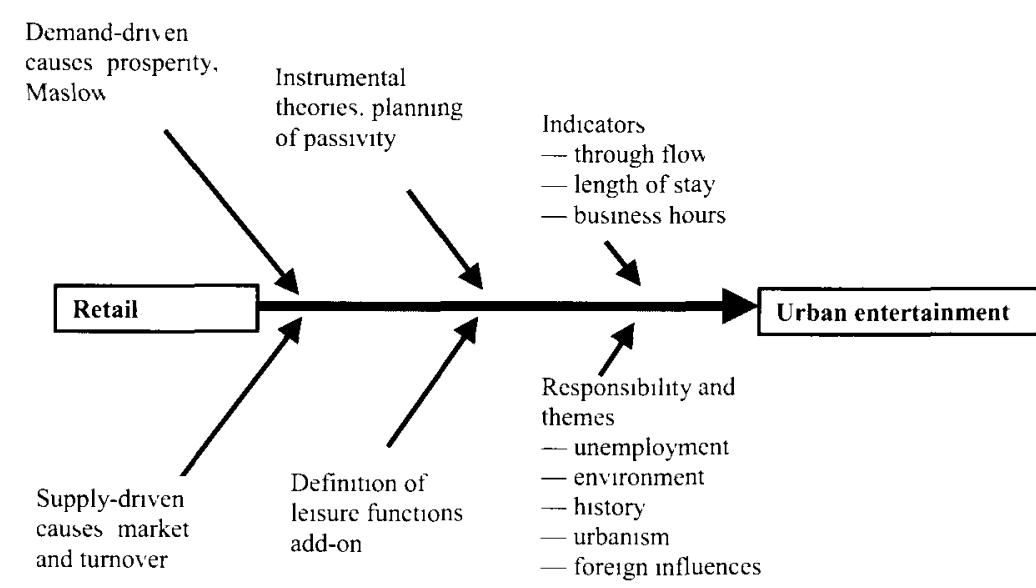

Figure 1: Transformation of retall by leisure

arguments drawn from several sources. ${ }^{4}$ According to the ULI, the retail sector is the starting point and urban entertainment the aimed result. The real estate world has mainly conceptualised leisure as just an 'add-on' for this transformation; a programme or feature that is a separately recognisable entity (bottom middle in the figure). Market and turnover opportunities belong to the supplydriven causes.

The increase in the understanding of leisure ties in not only the changing views of experts but also with the change in consumer behaviour. Instrumental theories within the retail and real estate world focus on relaxation and passive enjoyment (Figure 1, top middle). Throughout history the main reference may differ (Freud, Packard or Pine and Gilmore), but this passivity is a common feature. According to these theories, leisure amenities and urban entertainment are intended to tempt consumers to extend the length of their stay. This is viewed as the (implicit) 'operationalisation' of the desired objective of leisure and urban entertainment. As background causes, growing prosperity and the pyramid of Maslow are cited: the theory states that only when a certain level of prosperity is achieved do culture and leisure become important to human beings.

Probably the Maslow theory has had its effects during the relatively quiet period of the post-war growth of welfare. Because of the growing welfare state the more luxurious goods and the more expensive leisure activities became step by step within reach of more and more consumers. Consumer behaviour nowadays is tending to go in two directions: it must be more efficient and focus more on recreation. ${ }^{5}$ These are two extremes that are only partly reconcilable. The 'consumption' of goods from shops as well as culture from museums is under great time pressure. Shopping and leisure activities are representing 'agenda problems'. They are competing with other domains (work, education, care of children 


\section{'Efficient' leisure consumption}

Indicators and themes etc) and with each other. Every activity has to be done within strict space and time slots. Hence the need for efficiency. Additionally, the 'consumption process' must be more relaxed and recreational. Simply shopping for essential items and comparative shopping have made way for recreational shopping, which to a large degree is done for the experience and feel-good factor. ${ }^{6}$ Consumers are looking for added value; perhaps to compensate for the tougher working conditions today. ${ }^{7}$

In addition, a notable phenomenon is evident. Areas that in the past were separate are beginning to merge. Now there are shops everywhere: at the station, at the airport, beside the football stadium. What is more, the notion of culture is becoming blurred: apart from a visit to a museum, some people class a visit to a football match as culture. Consumption seems to be the common denominator for all these activities. ${ }^{8}$

Combining the need for efficiency and the need for leisure, one arrives at what Mommaas calls the 'guaranteed return on experience'. ${ }^{9}$ A family takes the car for a day trip to a leisure park, not to sit in a traffic jam or to see that attractions are out of order, but to enjoy themselves to the limit within a set period of time. In short, everything must work properly. What goes for the leisure park also goes for every other destination, including the outlet centre, the furniture centre and the department store and supermarket of one's choice.

This paper has only partly addressed the 'what' question. Many rejuvenation projects in the Netherlands include leisure and urban entertainment in the plans without knowing what exactly this entails. The term is used and even the number of square metres is allotted, but people cannot say precisely 'what' is involved. Additionally, there are the obligator discussions about causes and the required efficiency.

Management policy and management indicators have changed somewhat (Figure 1, bottom right and top right). In British megaprojects such as Bluewater near London, the fight against unemployment and tackling environmental problems have played a part in convincing the concerned parties about the necessity of the project. History is a recognised theme that inspires a certain level of confidence among consumers. This approach can be found in much post-modern architecture. The Netherlands has, until recently, had little involvement in this. The Designers Centre in Roermond, with its historical features and furnishings, is one of the few exceptions. In the Netherlands, urbanity is important. This objective is high on the agenda in the projects in Almere, Amersfoort and Rotterdam (see the Intermezzo section). In addition, whether a project was successful abroad plays a part, although to a much smaller degree than was the case in the past. This is understandable because foreign success and urbanity are, to a large degree, mutually exclusive. Urbanity in the Netherlands takes the local area as its point of departure. Foreign blueprints and concepts often do not fit 


\section{Goals of leisure in retail and real estate}

into the existing urban context. Dutch planning policy always take account of historical town centres and the existing city scape. This focus will be continued even within a more liberated and marketoriented planning paradigm.

Two well-known indicators of success are the length of stay and through flow. The length of stay has become an indicator of consumer expenditure, and the layout and management of shops are designed to prolong the length of stay. At the same time, the length of stay must be balanced with the through flow. Every shop - not just supermarkets - should be laid out efficiently. Business hours are a recent addition to this. Dutch shops have for some years had longer opening hours. In the urban context of the renovation of Rotterdam station, the extension of opening hours goes hand in hand with the objective of making the future station safer. If people are on the streets at night, then in theory social control is much greater.

\section{WHO: RETAILING AND REAL ESTATE}

About five years ago the word 'leisure' began to appear in Dutch retail and real estate journals. As far as retail was concerned, leisure could compensate for falling or lower growth in turnover - at least, that was the expectation. This expectation arose when the bottom fell out of the market. Afterwards, when turnover began to improve, the term 'leisure' appeared less frequently.

The same holds for real estate. When at the beginning of the 1990s turnover began to stagnate, developers and investors assiduously went looking for other opportunities. Shops became of greater interest to them, but shops like business premises represented a difficult market. One of the reasons is the small number of suppliers and customers. There is more talk of a one-toone relationship between retail and real estate and the segment is frequently termed 'exploitation dependent', which means that the failure or success of this market niche is highly depending on the management running the outlet. In short, the market, with its meaning of competence between large anonymous numbers, to a large degree has no particular character.

Nonetheless, the term 'leisure' is a permanent fixture in the vocabulary of the retail and real estate sectors. A factory outlet like the one in Roermond or the city centre in Almere can be exploited from the point of view of tourism. Complementarity with respect to existing amenities has a role to play but on top of this the retail trade has changed extensively. Most shops today choose a more spatial and associative method of presentation that ties in with the more differentiated consumer behaviour. The attention of both advertising and the retail environment has been shifted from the technical characteristics of product to its use and user - for example, from the dress to the woman and her opportunities to wear it. Needless to say, these associated social constructs are young, vital and promising. ${ }^{10}$

Important in the spreading of concepts such as leisure and urban 
Spreading of concepts

\section{Definitions of urban entertainment}

entertainment was a publication in 1998 from the ULI called Developing Urban Entertainment Centers. ${ }^{11}$ This publication provides a definition of urban entertainment and describes a number of examples. It details the plans and projects that came into being in the previous ten years, and covers urban entertainment projects such as Navy Pier in Chicago, Third Street Promenade in Santa Monica, New York City's Chelsea Piers and Times Square district, the variety of projects in Las Vegas, Universal City Walk and Walt Disney's Downtown Disney in Los Angeles, etc. Outside the USA the reader will find CentrO in Oberhausen (Germany) and Canal City Hakata in Japan.

The projects described by the ULI are showing different combinations of retail, leisure and restaurants, but always themed and expressing an urban atmosphere. The separated worlds of retail and leisure became combined and changed their characteristics forever. The projects have frequently acted as references during the formulation of Dutch projects over the last few years, which is connected with the search for new opportunities in retail and retail real estate. Also the history of retail was redefined: early examples of shopping centres of the 1930s like Country Club Plaza in Kansas City (USA) now became urban entertainment centres.

Important in the spreading of shop blueprints and real estate concepts were the times in the last 50 years when the various parties made an input. In the $1950 \mathrm{~s}$, retailers in the Netherlands began to import foreign ideas. Often it was not the big companies that started this trend, but they did ensure that the ideas were implemented correctly and on a massive scale - for example Albert Heijn (a part of Ahold) with supermarkets and self-service. ${ }^{12}$ Subsequently, the leisure industry (1970s), real estate developers (1980s) and 'industry outsiders' such as BP and KPN (1990s) began to become interested in blueprints and retail real estate (Figure 2). The small scale of the supply and the separate sectors are, as a result, barely recognisable. The retail sector, the real estate sector and various media are becoming increasingly interlinked. ${ }^{13}$ The current hybrid structure of the supply is a consequence of this.

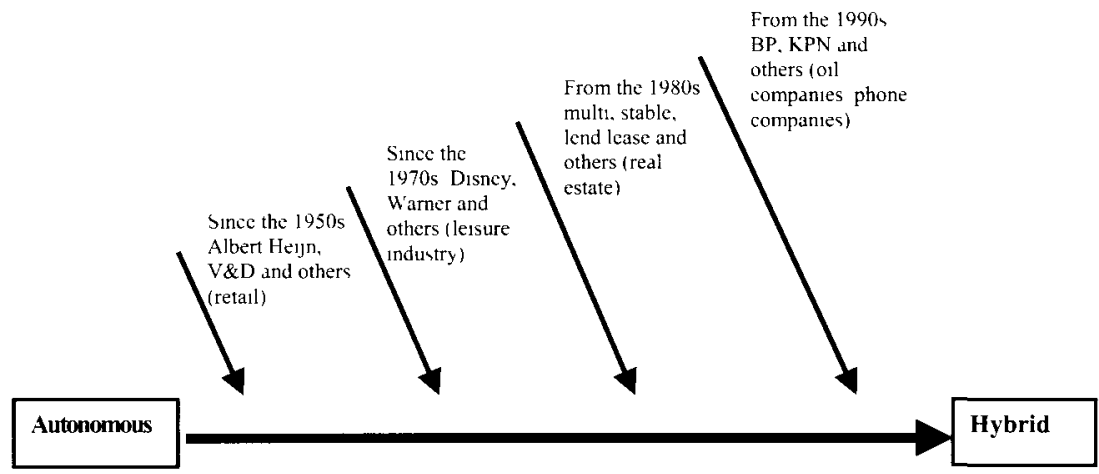

Figure 2: Hybridisation in the distribution of blueprints and shop types 
Internationalisation

Effects

West Edmonton Mall

\section{WHERE: THE WESTERN WORLD}

An increase in scale, modern distribution methods and the current - more mixed - supply and demand relationships are characteristic of the Western world in particular: North America, Western Europe, Japan, Australia and so on. Shops and leisure are undoubtedly issues for internationally operating companies and consumers. This goes for the international leisure industries like Disney but also for a Dutch supermarket company like Ahold. Ahold, for example, achieves 75 per cent of its turnover abroad. A concept that is successful abroad will also be tried in the Netherlands - a recent example of this phenomenon is the factory outlet centre. ${ }^{14}$ In addition, demand is more international than ever. Consumers travel abroad on holiday more than once a year.

Destinations are not limited to the adjacent countries.

Combinations of shops and leisure activities can be found today on a wide scale in the parts of the world listed earlier in the form of so-called 'resorts'. Leisure is within reach of virtually everybody at the moment. ${ }^{15}$

The process of globalisation does not imply that everything has become homogeneous. The fact that 'borders are opening up' does not open the door, and what is more, this statement is not completely true. Two examples: one on the supply side, one on the demand side. Like Marks \& Spencer in Europe, Ahold has make efforts to gain a foothold in South-East Asia. These have only been partially successful. And secondly, if consumer behaviour is 'blurring borders' because the museum goer can sometimes be found in a football stadium, that is not to say that every football fan also visits museums.

\section{WHEN: SINCE 1983}

The first time that leisure was combined on a large scale with retailing was in the West Edmonton Mall in Canada. This megamall was built in three phases between 1981 and 1985. The West Edmonton Mall is of interest because dates can be fairly precisely determined. The first phase comprised a quite small but typical shopping centre. It included an elongated, covered promenade with small shops right and left, and two big 'attractions' (anchor stores) at either end. The second phase heralded a dramatic change of direction. In 1983, an extensive leisure programme was added to the shops. The first phase is the most easterly section of the mall; the extensions of 1983 and 1985 are at right angles to the original direction.

The issue of dating can be addressed if a 'first' example can be found: the 'first' urban entertainment centre, the 'first' time that the term leisure was used and so on. The West Edmonton Mall is such an example (Figure 3). The time arrived at is really dependent on the point of view and the country. Tourism provides a different chronology than the retail sector. Tourism and the retail sector in the USA provide different results than in the Netherlands. ${ }^{16}$ 


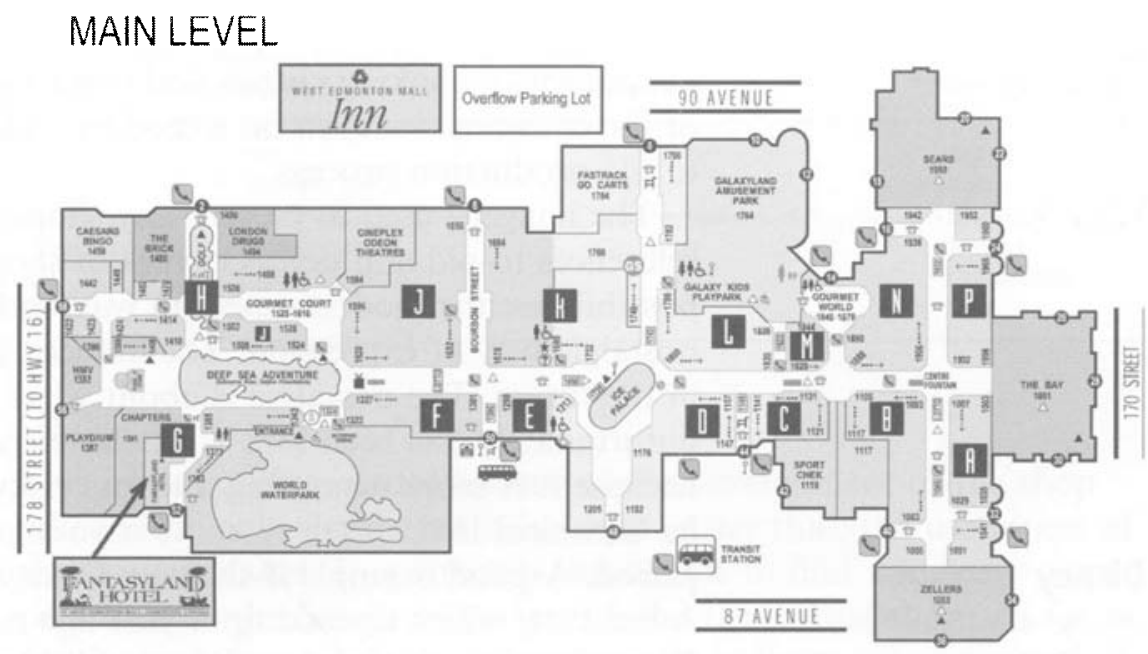

Figure 3: The first large-scale leisure mall West Edmonton Mall, Edmonton, Canada Source. West Edmonton Mall

Tourism began to experience worldwide growth around 1975. This has, among other things, led to resorts in all corners of the world. The combination with retail, as the West Edmonton Mall showed, was established from the mid-1980s onwards. Close behind was the UK with malls like the Metro Centre (Newcastle), the Merry Hill Centre (Birmingham), Meadowhall Shopping and Leisure Centre (Sheffield), Lake Side Thurrock and Bluewater (both east of London). The shopping centres in Wijnegem (Antwerp, Belgium) and CentrO (Oberhausen, Germany) are, like Bluewater, examples of the 1990s.

The continental projects are much smaller than the American

UK versus USA

Stimuli and senses and UK examples - about half the size of the UK shopping malls. As already stated, leisure and retailing have been more intensely combined in the Netherlands for about the last five years. Reasons that prohibit the implementation of large-scale shopping malls are the local planning policies expressing care for existing town centres and shopping amenities. What in the Dutch context is called the 'periphery' is still at the edge of the city borders and not the out-oftown, middle-of-nowhere locations of most foreign examples. The Dutch retail and leisure environment is indeed growing into the Anglo-Saxon model, but the scale of the new outlets is modest.

\section{HOW: VISUALLY AND INTERACTIVELY}

The history of the shop is in general terms the history of the interaction between the retail area/presentation and the 'consumer'. In the first 100 years (19th century), this interaction was achieved using imagery. In the last 100 years (20th century), the palette of stimuli has been broadened substantially. Apart from imagery, the consumer is also stimulated by texture, smells, sounds and so on. Above all, his or her role today is much less passive. The consumer was already strongly coupled to the distribution process by the self- 
Disney

Metaphors service system found in department stores and supermarkets; with the advent of cooking classes and other events inside shops, the role of the consumer - even on a modest scale - is becoming coupled to the production process.

The imagery used in present-day shops nearly always contains references to old and defunct types of shop. In theory there are two possibilities: the modern, utopian way and the historical, somewhat nostalgic way of expression. The modern is about what is to come in the future. The nostalgic is about what people have had, but unfortunately has been lost. ${ }^{17}$ The latter is favourite now, perhaps because it is more reassuring and less risky. The modern way with its 'technical look' often refers to a younger but still historical period. A good example is the new Disney leisure park, California Adventure, which opened up a year ago near the existing Disneyland in the Los Angeles area. Where Disneyland is referring to villages and main streets of the 19th century, California Adventure is referring to film industries and street life of the 1930s to 1950 s period of the 20 th century.

The use of historical images makes the history of the development of the shop to a large extent metaphorical. The royal gardens were recognisable in the covered shopping streets of the arcades, department stores had great similarities with theatres, supermarkets imitated vegetable markets and suburban shopping centres needed to offer an alternative to existing city centres in terms of social value (see Table 1 for a chronological overview). The implications for real estate and developers are manifold. They have to be sensitive to these trends, like the life cycles of design and, to mention a practical issue, reserve more square metres per customers in their shops in shopping centres.

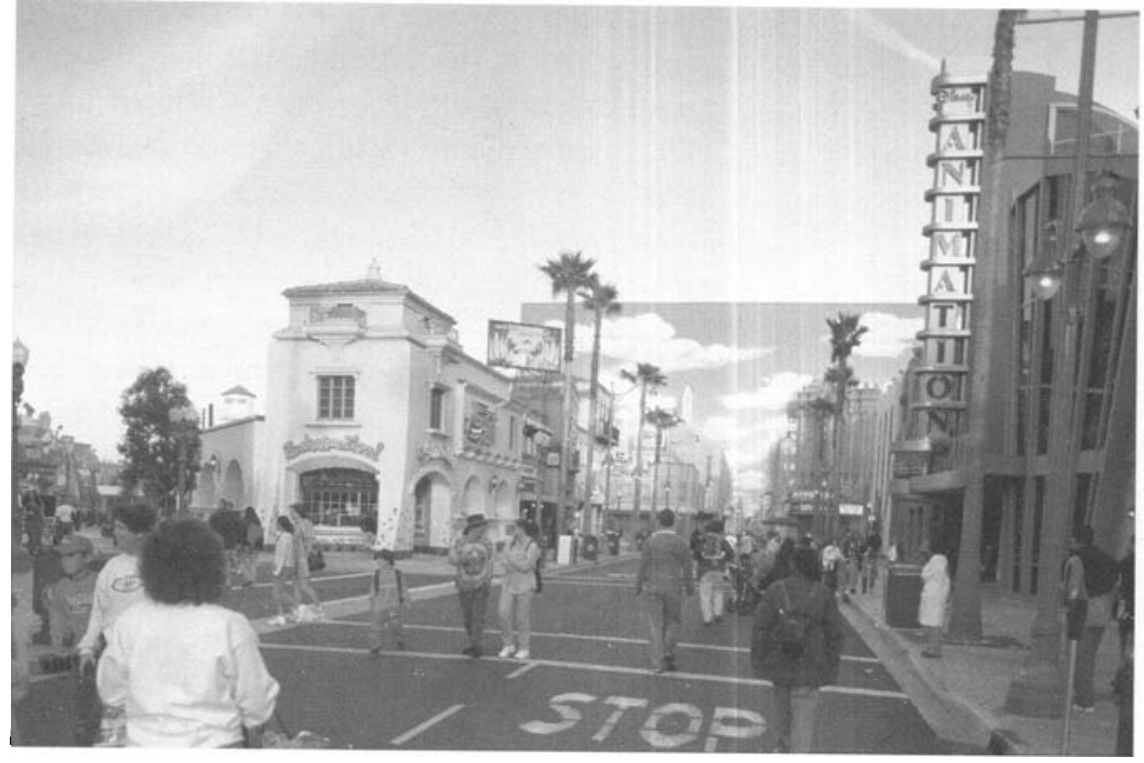

Figure 4: Modern-nostalgıc focus on the film industry: Calıfornia Adventure, Anaheım. Calıfornia. Photo: D. Kooljman 
Table I: History of shop types, $1800-2000$

\begin{tabular}{llll}
\hline Year & Shop type & Reference & Affected senses \\
\hline 1800 & Arcade & Royal garden & Sight \\
1850 & Department store & Theatre & Taste \\
1925 & Supermarket & Fresh vegetable market & Smell \\
1950 & Shopping centre & City centre & Hearing \\
1975 & Furniture boulevard & & Combination \\
2000 & Virtual shop & & Sight
\end{tabular}

This metamorphic partial history of the development of the shop takes in roughly the period 1800-1975. After that, the usefulness of the imagery fades. It is virtually impossible to find a logical precursor to the furniture boulevard and the virtual shop. As far as furniture shops and shops selling household items are concerned, it is very difficult to discern a 'boulevard'. Nothing about these places reminds one of the famous Parisian avenues. Imagery is completely missing from virtual shops, or else an abstract city is used as a metaphor. The vitality of the imagery is really at a low level in these examples.

It appears that the current palette of stimuli must compensate for the loss of the imagery. No technique remains unexploited in attracting the consumer to products and services in the shop. 'The biggest kitchen in the world' is the latest tag line in Albert Heijn commercials. ${ }^{18}$ This places all the products literally and figuratively in a spatial framework ('the kitchen'). The supermarket chain has already set up cooking schools inside its shops. Consumers can (learn to) prepare meals with ingredients from the supermarket. Apart from the fact that the activities in the cooking classes are product driven, the spatial presentation has notably found an image from the private domain: the kitchen.

\section{INTERMEZZO: FOUR DUTCH PROJECTS AS AN ILLUSTRATION}

Omniworld in Almere, a theme centre in Amersfoort, a designers' outlet centre in Roermond and a programme for urban

entertainment close to the future Rotterdam central station are four Dutch projects, of which only 'Roermond' is complete - it opened in November 2001. It is, in fact, a so-called factory outlet centre and was designed by McArthurGlen. The other three projects are in the planning stages but provide a good indicator of the initiators' objectives. Urban councils are the initiators of all three projects, but as soon as the implementation phase begins, they will set up a private limited company or cooperate with private concerns. Table 2 lists a number of the objectives. Table 3 shows the area in square metres of the different parts of the projects. A complicating factor is that leisure and retail are often parts of an overall real estate plan and are not always immediately recognisable. The size of the overall project varies, but with the population figures included, an indication of the probable relationships is provided. 
Table 2: Objectives and themes for the four Dutch case studies

\begin{tabular}{|c|c|c|c|c|c|c|c|}
\hline & Objective & Theme & Programme & Anchor & Initiative & Implementation & $\begin{array}{c}\text { Planning } \\
\text { phase }\end{array}$ \\
\hline Almere & Urbanısm & Top sport & 145,000 & Sport? & Urban councıl & NV Omniworld & Planning \\
\hline Amersfoort & Urbanısm & Media? & 63.750 & Culture & Urban counal & Private bodies & Plannıng \\
\hline Roermond & Convemence shopping & Desıgner clothes & 12,500 & City centre & Private body & Private bodies & Constructed \\
\hline Rotterdam CS & Public area & Film? & 635,000 & Mobility? & Urban council & PPP & Planning \\
\hline
\end{tabular}

Table 3: Background characteristics of the four case studies

\begin{tabular}{|c|c|c|c|c|c|c|c|}
\hline \multirow{2}{*}{$\begin{array}{l}\text { Almere: Onmiworid } \\
\begin{array}{l}\text { Number of town } \\
\text { Inhabitants }\end{array}\end{array}$} & \multirow[b]{2}{*}{140,000} & \multicolumn{2}{|c|}{ Amersfoort: Theme centre } & \multicolumn{2}{|c|}{ Roermond: Designer clothes } & \multicolumn{2}{|c|}{ Rotterdam: Central Station } \\
\hline & & $\begin{array}{l}\text { Number of town } \\
\text { Inhabitants }\end{array}$ & 128000 & $\begin{array}{l}\text { Number of town } \\
\text { Inhabitants }\end{array}$ & 75,000 & $\begin{array}{l}\text { Number of town } \\
\text { Inhabitants }\end{array}$ & 600,000 \\
\hline Function & $\mathbf{m}^{2}$ & Function & $\mathbf{m}^{2}$ & Function & $m^{2}$ & Function & $\mathrm{m}^{2}$ \\
\hline Football stadium $(13,500 \text { seats })^{*}$ & * 60,000 & Multıplex & 8,100 & Retall ( 80 shops) & 12.500 & $\begin{array}{l}\text { Urban entertainment } \\
\text { (Incl. retall) }\end{array}$ & 121,000 \\
\hline Indoor sports hall ( 3,500 seats $)^{*}$ & * 10,000 & Cultural amenities & 5.250 & & & Hotel & 7,000 \\
\hline $\begin{array}{l}\text { Sport, entertainment (incl retail, } \\
\text { catering) }\end{array}$ & 20,000 & Multimedia centre & 18.000 & & & & \\
\hline Exhibition centre & $N / A$ & Independent caterıng & 1,400 & & & & \\
\hline Hotel & $N / A$ & Public facilities & 500 & & & & \\
\hline \multirow[t]{2}{*}{ Meetıng and congress centre } & $N / A$ & Small-scale retaıl & 2,000 & & & & \\
\hline & & Supermarket (underground) & 4,000 & & & & \\
\hline Offices & 85.000 & Offices & 14,500 & & & Offices & 318,000 \\
\hline Dwellings ( 400 in total) & 40,000 & Apartments (100 in total) & 10,000 & & & Dwellıngs $(1,200$ st $)$ & 195.000 \\
\hline Total & 215,000 & Total & 63,750 & Total & 12,500 & Total & 641,000 \\
\hline
\end{tabular}

*Combined $70,000 \mathrm{~m}^{2}$

$\mathrm{N} / \mathrm{A}:$ Not applicable

Urbanity
The objectives of the projects are often related to urbanity. This is not particularly surprising when one considers that the projects will often be built in the middle of the city. The term 'urbanity' is not always well defined, but people do not only want to go into the city to shop, or just to enjoy themselves. Amersfoort talks of a 'new heart for the city'. ${ }^{19}$ The place where the new centre is to be built was an important criterion. Almere views Omniworld as the "centre of a new part of the city' because of the extensive and varied scope of the project. ${ }^{20}$ Rotterdam does not just want to renovate its station, in future the area around the station, which will take shape in phases between 2003 and 2018, must specifically become an integral part of the inner city. ${ }^{21}$ Roermond is at first sight different: the project has a clear objective from a retail perspective (Figure 5). Visitors must be also to shop easily. But at the same time, the factory outlet could not exist without the inner city of Roermond. The city council and the developers are aiming for combined visits. The inner city is clearly an important attraction. To exploit this fact, the urban council has built a pedestrian tunnel to streamline the connection between the factory outlet and the city centre. ${ }^{22}$

All the projects have been themed more or less from the outset. 


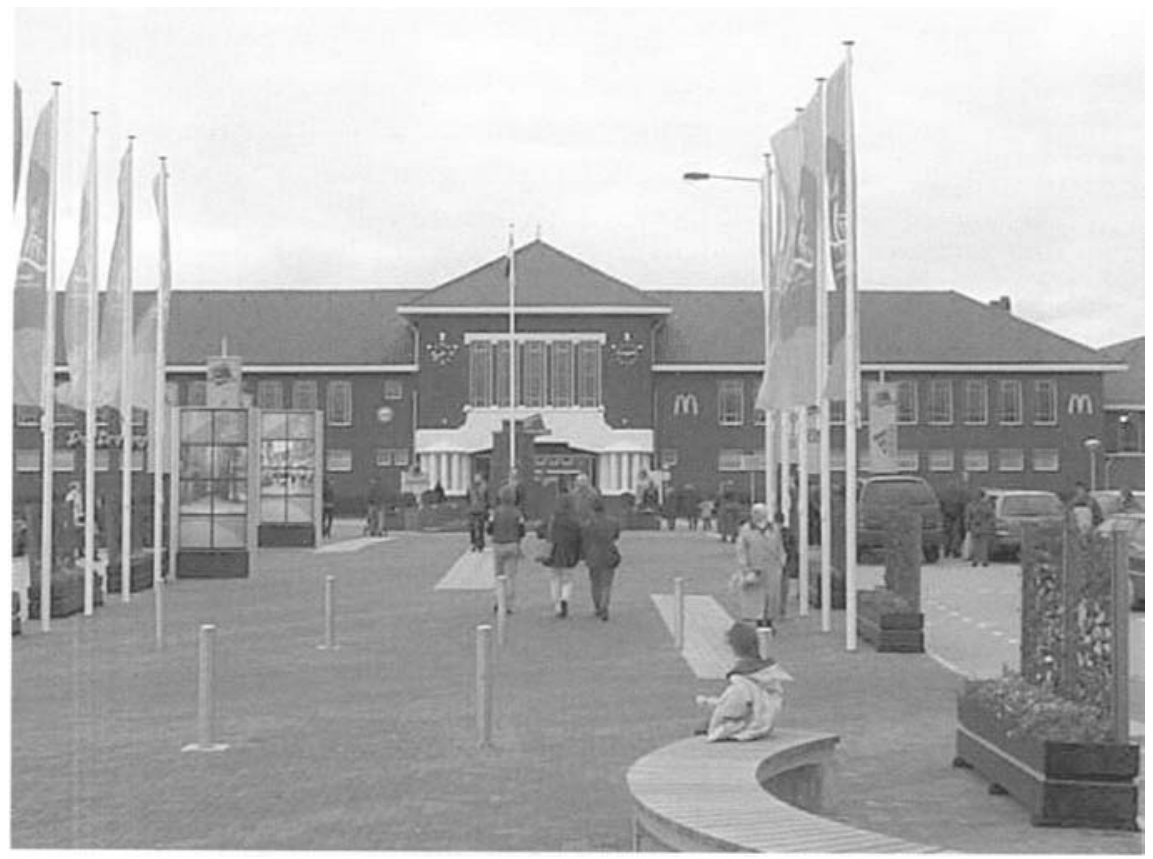

Figure 5: One of the two factory outlet centres in the Netherlands: The Designers Outlet Centre in Roermond. Photo: D. Kooljman

Theming

This is clear to see at the outlet centre in Roermond. The visitor expects designer clothing at greatly reduced prices, but the historical architecture only makes sense because of the proximity of Roermond city centre. For Amersfoort and Rotterdam, the actual theme is not yet clear. In the case of Rotterdam (Figure 6), urban entertainment is necessary in order to complement the current retail

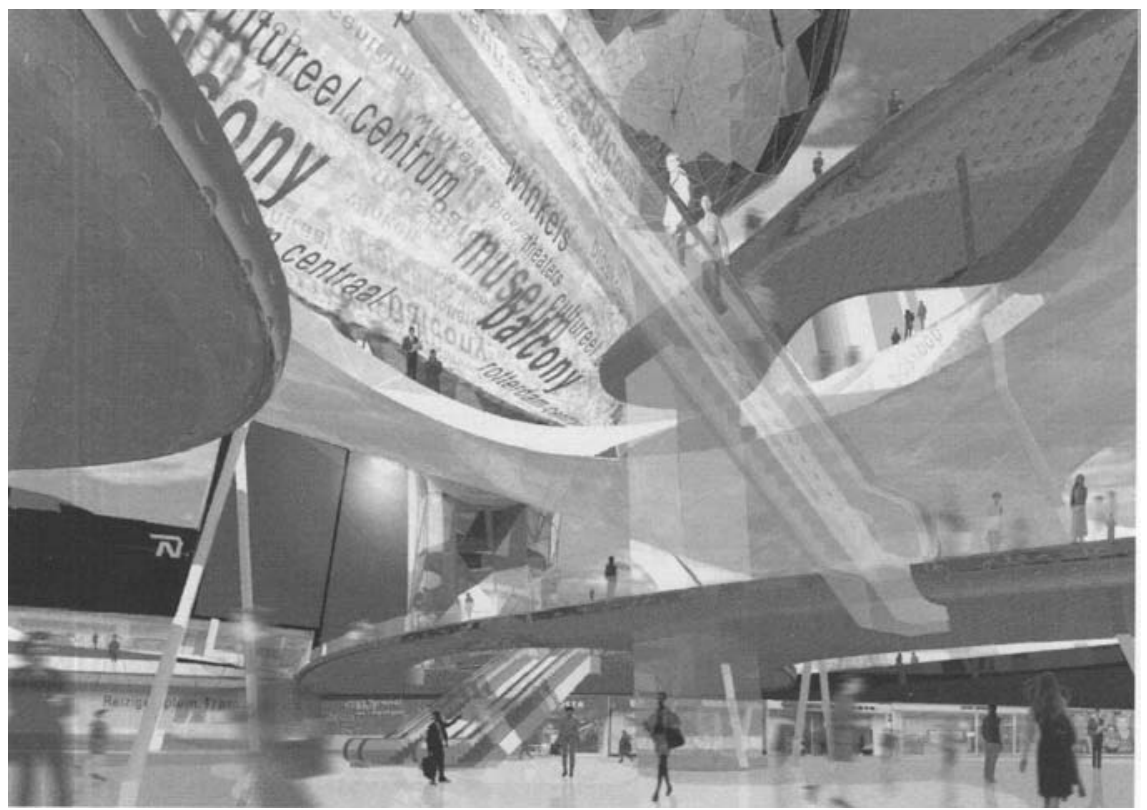

Figure 6: Mobility and city life in the master plan of Rotterdam Central Station, designed by William Alsop. 
Theming and the planning process

First revolution trade in the existing city centre. Behind closed doors there is speculation about the possibility of coupling the urban entertainment programme with an attraction of the city. The annual film festival sparked the idea of taking 'film' as the theme. In Amersfoort, things are less clear regarding the content of urban entertainment. The use of a theme is seen as necessary. A media centre where one will find the public library in combination with all kinds of suppliers of 'new media' therefore forms a considerable part of the plans: about half of the area in fact, if one ignores offices and dwellings. But at the same time there has been almost hopeless deliberation over which theme to choose. Various themes have been suggested - nature and the environment, technology and science, people, art and culture, the city, Europe - but no choice has actually been made.

The implementation phase of the plans for Almere, Amersfoort and Rotterdam is still some way off. The objective from the perspective of urbanity is usually more understandable. The choice of theme is much less clear. Future success is dependent on a combination of factors; a combination that the project initiators are searching hard to find in view of the proposed plans.

The use of a theme is seen as a necessity. Only this way can an urban entertainment project attract enough people. The uncertainty about the content of the theme has to do with marketing. At the moment one has found a retailer or other supplier; the real theme is there. What was unclear and vague in the marketing phase becomes clear when exploitation is about to start. The scale and content of current plans and areas needing attention require a message that leaves nothing to the imagination: not for consumers but also not for the various public and private bodies that today are ranged against each other. In the four Dutch projects described, the urban council is identified as the project initiator, but as soon as the project becomes viable market players come into the picture. The complexity of the plans and the complicated financing can no longer be taken on by any of the parties on their own.

\section{WHY: THREE RETAIL REVOLUTIONS}

A valid way of explaining the developments in the retail sector is the notion of the so-called 'retail revolution'. The literature speaks of two revolutions: the first took place in the 19th century: the second occurred in the 1950s and 1960s. ${ }^{23}$

The first retail revolution was brought about by an evolution in the relationships within the distribution sector. This revolution followed the (political) French Revolution and the (economic/ technical) Industrial Revolution. In the 19th century, the distribution sector became an independent economic entity of the production sector. Producers could not handle the distribution of consumer goods and even independent hawkers had seen their best days. Instead of the production sector, the distribution sector took the lead. As nearly all the modern department stores and 


\section{Second revolution}

\section{Third revolution}

\section{Different countries}

\section{Hybrid forms}

supermarket chains show, the distribution sector often commissioned the production of their own goods or started their own plants. An increase in scale was an important factor in social success, achieved by a substantial reduction in prices combined with a larger turnover. This revolution was mainly driven by demand.

The second retail revolution took place in the 1950s and 1960s. New concepts and shops such as self-service, supermarkets and shopping centres increased the efficiency of the distribution chain and reduced the associated costs. Suppliers then began to compete with each other.

It is not an exaggeration to speak of the current combination of retailing, leisure and urban entertainment in terms of a third retail revolution, because of the (new) hybrid nature of the distribution sector. There are new combinations of once-separate types of shop (for example, the mix of supermarket and department store), new consumer behaviour (leisure/recreational shopping compared with ordinary day-to-day buying) and new suppliers (oil companies, telephone companies and so on). ${ }^{24}$ Figure 2 shows a cross-section of the changes.

In North America, this third retail revolution has two important variants. The first variant was the so-called mega-mall where shops, catering and leisure were united in a large-scale complex. Examples are the West Edmonton Mall in Canada and the Mall of America near Minneapolis in the USA. This type of large-scale development arrived in Europe mostly via the UK. These mega-malls are usually independent projects on the outskirts of town. The second variant took the form of the rejuvenation of the (American) inner cities. Boston, Baltimore, Detroit and New York received more attention for their inner cities in the 1980 s, resulting in 'waterfront' projects combined leisure and retailing in an urban environment. ${ }^{25}$

These extremes are less recognisable in the Netherlands because mega-malls are unknown and the rejuvenation of cities is not as necessary. Dutch environmental policy, in contrast to that of a large number of American cities, has always paid attention to the historical inner city. Environmental policy and the associated planning system, as well as the relatively high number of square metres per inhabitant, have put a brake on these developments. Historical cities, unlike in the USA, have always been protected. Above all, more attention has been paid to the relationship between new concepts and the existing supply.

The four Dutch cases show much attention to leisure and entertainment. The use of these English expressions the past few years are an obvious indicator of a renewed orientation towards trends in the Anglo-Saxon world. New combinations of retail and leisure are proposed or already built. Putting different amenities together will provide synergy for the supply side as well as for the demand side of the urban entertainment projects. The long-lasting Dutch tradition of urbanity is different to the invented version of projects such as Universal City Walk or Disney Down Town. In the 


\section{Planning uncertainty}

Los Angeles region the city is a kind of decor for existing leisure outlets. When the ULI called Universal City Walk the archetype of urban entertainment destinations the statement refers mainly to the USA. $^{26}$

The market orientation in the four cases is represented by the use of a variety of ppp-constructions (public-private partnerships). The 'new suppliers' - as indicated, one of the elements of the 'third revolution in retail' - are there too. Examples are the UK developer bringing the concept of the factory outlet centre to Roermond. In Almere the sporting organisation OmniWorld is very much involved. In Amersfoort and Rotterdam they will show up when the market search is completed and the operation by shop and retail holders comes into the picture. Now the initiators only have a global idea where to look ('media' and 'film' respectively).

\section{CONCLUSION}

This paper has examined leisure and urban entertainment mostly from the perspective of the retail and real estate sectors. It would be straying too far off the point to discuss the leisure industry separately. As it is, there are enough questions that remain to be addressed in terms of research and education. The Dutch position in the international sphere of influence is not obvious. There are various trends in globalisation that demand a critical assessment. The leisure industry is at the moment characterised by all sorts of management takeovers. The real estate sector is, more than ever, at the forefront of introducing new concepts to the Netherlands. Leaders seldom come from abroad.

At the same time, the monomaniacal focus of the retail and real estate sectors on the USA should be treated with scepticism. The shopping mall and urban entertainment are not - as has been well proved - export items over which the USA has sole rights. The importance of good marketing goes without saying, but some critical reflection is in order. A nice counter-example is the Lijnbaan in Rotterdam. Plans for this shopping centre were on the drawing board as early as 1948 and it was opened in 1953. As such, it was one of the first examples of a shopping mall in the world. It gets better because today one could also call the Lijnbaan an urban entertainment centre, as this mall lies in the middle of the city.

\section{References}

1 Davis, Dorothy (1966) A Historl of Shopping, Routledge and Kegan Paul, London, p. 276: Miellet, Rogier and Voorn. Marieke (2001) Winkelen in Weelde Warenhuzen in West-Europa 1860-2000, Walburgpers, Zwolle. pp 23, 70

2. A good international comparison of retail politıcs was made in Péron. René (2001) 'Political management of change in urban retallng', International Journal of L'rhan and Regional Research, Vol 25, No 4, pp. 847-878.

3. Urban Land Institute (1998) Developing L'rhan Entertalnment Centers, Urban Land Institute. Washıngton, DC, p. 5.

4 Craenen. J. (2000) 'Urban entertanment and shopping fun'. in MRE Masterretail (series of three papers); DTZ Zadelhoff (2001) Rotterdam Centraal Marktwiste en 
Markttechntsche Aspecten. DTZ. Utrecht; Kolpron (2000) Samenvatting en Integratie Marktverkenningen Rotterdam Centraal, Kolpron Consultants, Rotterdam; Marijnıssen, R (1999) 'Leisure: Economisch perspectief voor stad en regio', paper presented to the Vastgoed en Leisure symposium of the Netherlands Studiecentrum, 17th June; Jansen. Louis and Pluijmers, Ben (2001) 'Beleggers en lessurevoorzieningen', Real Estate Magazine, No. 17. pp 38-43.

5. de Haan, Jos, van den Broek, Andries and Schnabel, Paul (2001) Het Nieuwe Consumeren Een Voorutblik Vanut Demografie en Indvidualtsering. Sociaal en Cultureel Planbureau, Rijswijk. Work Document 72; Kooijman, Dion (1999) Machune en Theater Ontwerponcepten van Winkelgebouwen, 010 Publishers, Rotterdam.

6. Pine, B. Joseph, and Gilmore, James H. (1999) The Expertence Economy Harvard Business School Press. Cambridge, MA

7 Sennett, Richard (1998) The Corrosion of Character The Personal Consequences of Work in the New Capitalism, W. W Norton, New York, Castells, Manuel (1996) The Rise of the Network Societr. Blackwell, Oxford.

8 Jameson, Fredric (1998) 'Globahzation as phılosophıcal issue', in Jameson, Fredric and Miyoshı, Masao (eds) The Cultures of Globalizatın. Duke University Press, Durham, NC.

9 Mommaas, Hans, Knulst. W and van den Heuvel, M (2000) De Vruetiydsindustrle $m$ Stad en Land. Een Studie Naar de Markt van Beleventssen, SDU (WRR Voorstudies en Achtergronden). The Hague.

10 Leiss, W., Kline, S and Ihaly, S. (1997) Soctal Communication in Advertising. Persons, Products, and Images of Well-betng. Routledge. London

11. Urban Land Institute, ref. 3 above.

12. Koorjman, ref. 5 above, pp 92-100.

13. Sassen, Saskıa and Roost, Frank (1999) 'The city' Strategic site for the global entertainment industry", in Judd, Dennıs R. and Fainsteın, Susan S. (eds) The Tourtst City, Yale Unıversity Press, New Haven, CT, pp 143-154.

14. Meıjerıng, A. P. (2001) Factory Outlet Centers Een MERKwaardige Ontwikeling. Arko, Nieuwegen

15 Bastıaansen, Jeroen (2001) 'Vormgeving van leısure-elementen in binnenstedelijke gebieden', masters thesis, University of Delft.

16 Morley, Stuart and Evans, Chris (2000) 'The future for lessure property in the UK' Journal of Leisure Property. Vol 1, No. 4, pp. 22-25.

17. McClung. Willem Alexander (2000) Landscapes of Desire. Anglo Mythologies of Los Angeles, Unıversity of Calıfornıa Press, Berkeley; Hannigan. John (1998) Fantasy City. Pleasure and Profit in the Postmodern Metropolis, Routledge, London/New York

18 Smit, Richard (2001) 'In de keuken van Albert Heijn", Adformatle, No. 34, 23rd August, pp. 20-21.

19. Gemeente Amersfoort (2000) Rapportage Themacentrum, Amersfoort, www amersfoort.nl

20 www migrate omnıworld.nl.

21 Alsop Architects with Combined Design Team (2001) Ontwerp Masterplan Rotterdam CS, Alsop, Rotterdam

22 www.designeroutletroermond com

23 Davis, ref 1 above; Miellet and Voorn. ref. 1 above. Miellet and Voorn have stressed the more technical changes like the self-service system etc. Davis seems more accurate because she is focused on the demand-supply relationship, thus she can clearly correlate the first revolution with demand and the second with supply.

24. Beyard, Michael D. and Rubın. Michael S. (1995) 'A new industry emerges", Urban Land, August. p. 6.

25. Urban Land Institute, ref. 3 above.

26. Beyard and Rubin, ref. 24 above. 